\title{
Effect of water vegetation on lowland stream during two season
}

Tatiana KIMLIČKOVÁ ${ }^{1}-$ Radoslav SCHÜGERL ${ }^{2}$

1: Institute of Hydrology, Slovak Academy of Sciences, Dúbravská cesta 9, 84104 Bratislava, Slovak Republic; E-mail: kimlickova@uh.savba.sk

2: Institute of Hydrology, Slovak Academy of Sciences, Dúbravská cesta 9, 84104 Bratislava, Slovak Republic; E-mail: schugerl@uh.savba.sk

Key words: water vegetation, lowland stream, discharge, water-level

\section{Introduction}

Vegetation in the water along lowland streams has been the subject of several studies since it was recognized that it could have a significant impact on the water flow. It may increase resistance to flow and cause higher water levels. Also, it has affects on the velocity profiles. For flow of water through emergent vegetation, previous investigations show different results (Carollo et al., 2005; Velísková et al., 2017). The aim of this paper is to investigate and determine, how water vegetation influence flow resistance, water depth and discharge in the Malina stream at the Záhorská lowland (Slovakia).

\section{Materials and methods}

Paper describes measurement of discharge by ADV (Acoustic Doppler Velocimetry) method (Flow Tracker device), which is suitable for discharge determination in measured cross-section profiles, or for determination of distribution of average velocities in verticals. Determination of free-level stream in cross-section profiles is given by GPS device STONEX S9 IIIN (GNSS - Global Navigation Satellite System).

The aim of this contribution is to demonstrate on the base of results from experimental field measurements on the Malina stream at the Záhorská lowland (Slovakia), how the sprouting of stream bed by water vegetation influences flow conditions in the channel and its capacity.

\section{Results and discussion}

The value of discharge and water-level in sprouted stream bed is changing during the growing season in dependency on water vegetation growth. In consequence of raised roughness, the velocity profile is changing and thereafter the discharge capacities, too. The rate of vegetation impact on flow regime during the vegetation season had been changed in each year differently, as well. It is reasoned because the each year had different climatic conditions that stimulated water vegetation growth.

Values of discharge $\left(\mathrm{m}^{3} / \mathrm{s}\right)$ and water-level (h.a.s.l.) obtained from two cross-section profiles were evaluated separately. Results are summarized in Table 1.

For example, in February 2017 (Fig. 1) value of the biggest discharge is 6-times higher $\left(1,177 \mathrm{~m}^{3} / \mathrm{s}\right)$, than value of the smallest discharge in July $2017\left(0,177 \mathrm{~m}^{3} / \mathrm{s}\right)$, whereas water-level is approximately the same. 
Table 1: Summary of measured data in two cross-section profiles (Gas-line and Railway bridge)

\begin{tabular}{|c|c|c|c|c|c|}
\hline Profile & Measure no. & Y (coord.) & X (coord.) & Discharge $\mathrm{m}^{3} / \mathrm{s}$ & Wat-lev. h.a.s.l. \\
\hline \multirow{6}{*}{ GAS-LINE } & 1 & \multirow{6}{*}{-581981.92} & \multirow{6}{*}{-1257295.11} & 0.384 & 141.559 \\
\hline & 2 & & & 0.609 & 141.26 \\
\hline & 3 & & & 0.929 & 140.91 \\
\hline & 4 & & & 0.168 & 140.981 \\
\hline & 5 & & & 0.323 & 141.3 \\
\hline & 6 & & & 0.201 & 141.415 \\
\hline \multirow{6}{*}{$\begin{array}{l}\text { RAILWAY } \\
\text { BRIDGE }\end{array}$} & 1 & \multirow{6}{*}{-581935.73} & \multirow{6}{*}{-1258668.15} & 0.408 & 141.077 \\
\hline & 2 & & & 0.714 & 140.979 \\
\hline & 3 & & & 1.177 & 140.621 \\
\hline & 4 & & & 0.177 & 140.721 \\
\hline & 5 & & & 0.37 & 140.942 \\
\hline & 6 & & & 0.194 & 141.003 \\
\hline
\end{tabular}

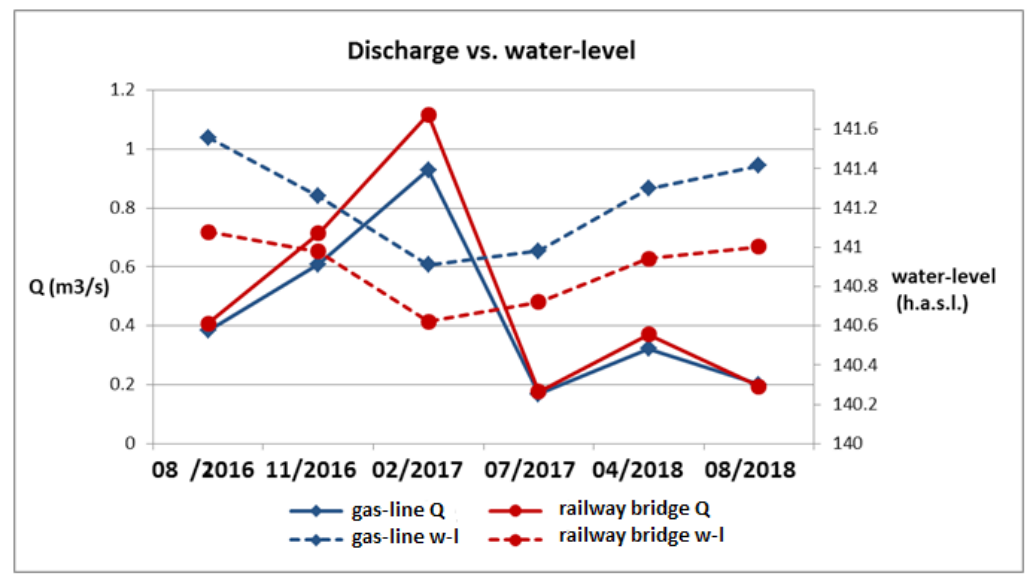

Figure 1: Discharge vs. water-level in two cross-section profiles (gas-line and railway bridge) during different season

\section{Conclusions}

The aim of this paper was determination influence of vegetation on discharge and flow-condition and water-level. Summary of the values are in Table 1 and Figure 1. Measurements of basic characteristics of Malina stream were performed during the two years. In consequence of growing vegetation the velocity profile is changing and water level, too.

\section{Acknowledgement}

This work was supported by the contract VEGA-02/0025/19 and APVV-14-0735

\section{References}

Carollo F.G., Ferro V. and Termini D. (2005): Flow resistance law in channels with flexible submerged vegetation. Journal of Hydraulic research, vol. 131, 2005, pp. 554 - 564.

Velísková, Y., Dulovičová, R., Schügerl, R. (2017): Impact of vegetation on flow in a lowland stream during the growing season. Biologia, vol. 72, no. 8, 2017, pp. 840 - 846. DOI: https://doi.org/10.1515/biolog-2017-0095 